Arq. Bras. Med. Vet. Zootec., v.63, n.3, p.591-594, 2011

\title{
Feline intraocular sarcoma associated with phthisis bulbi
}

[Sarcoma intraocular felino associado à phthisis bulbi]

\author{
E. Perlmann ${ }^{1}$, A.C.V. Rodarte-Almeida ${ }^{2}$, L. Albuquerque ${ }^{2}$, A.M.V. Safatle ${ }^{1}$, \\ J.A.T. Pigatto ${ }^{2}$, P.S.M. Barros ${ }^{1}$ \\ ${ }^{1}$ Faculdade de Medicina Veterinária e Zootecnia - USP \\ Av. Prof. Dr. Orlando Marques de Paiva, 87 - Cidade Universitária \\ 05508270 - São Paulo, SP \\ ${ }^{2}$ Faculdade de Veterinária - UFRGS - Porto Alegre, RS
}

\begin{abstract}
Two cases of feline intraocular sarcoma were reported in stray cats that presented blindness and hypotonia of the affected eye for years before the tumor development. Phthisis bulbi, a final stage of a severe inflammation of the eye, is frequently unmonitored because eyes are blind, small, opaque, and not painful. Yet, this report shows that monitoring and early enucleation of eyes of cats with phthisis bulbi are important and should be considered as a treatment option, because feline intraocular sarcoma is an aggressive tumor that significantly decreases live expectancy.
\end{abstract}

Keywords: feline, phthisis bulbi, intraocular, sarcoma, metastasis

\section{RESUMO}

Relatam-se dois casos de sarcoma ocular em gatos que apresentavam cegueira e hipotonia nos olhos afetados por anos antes do crescimento neoplásico. Phthisis bulbi, que é o estágio final de um processo inflamatório ocular intenso, geralmente não é monitorado por tratar-se de um olho cego, pequeno e não doloroso. O relato demonstra que o monitoramento e a enucleação precoce de olhos em phthisis bulbi são importantes e devem ser considerados como opções de tratamento, porque o sarcoma intra-ocular é agressivo e pode diminuir significativamente a expectativa de vida.

Palavras-chave: felino, phthisis bulbi, intra-ocular, sarcoma, metástase

\section{INTRODUCTION}

Chronic intraocular inflammation precedes the development of feline intraocular sarcoma (FIS), an important neoplasm, which is also described as post-traumatic sarcoma, because it is associated with a history of trauma. The denomination feline intraocular sarcoma is more precise, as the disease also affects cats with chronic uveitis with no history of trauma (Dubielzig, 2002). Intraocular sarcoma development has been described in a period from one to ten years following the initial trauma (Dubielzig et al., 1990). These tumors are extremely aggressive, with a high rate of recidivation, metastasis, and optical nerve invasion. Numerous authors agree that the tumor originates from the lens epithelium (Dubielzig et al., 1990; Stoltz et al., 1994; Zeiss et al., 2003). Dubielzig (2002) stated that these tumors are composed of spindle shaped cells that originate from the fibrous metaplasia of the lens epithelium.

The characteristics of feline intraocular sarcoma resemble those of feline post-vaccination sarcomas (Carter et al., 2005). One explanation is that certain cats might be genetically predisposed to develop this neoplasia in the presence of inflammatory or regenerative processes. The cells lose their antiproliferative properties and become malignant. In these cases, telomerase levels are increased. Feline intraocular sarcoma is not associated with any viral infection.

Recebido em 12 de março de 2010

Aceito em 4 de abril de 2011

E-mail: perlmann@ig.com.br 
The aim of this study was to report two cases of feline ocular sarcoma with a history of phthisis bulbi prior to tumor diagnosis.

\section{CASE REPORT}

Case 1: An 11-year-old mixed breed queen with buphthalmia of the right eye, which according to the owner had developed in the previous month. The animal was an adopted stray cat that at the time of adoption presented blindness of the right eye, with microphthalmia, hypotonia, and opacity. The clinical picture was unchanged up to the time of clinical evaluation.

Ocular ultrasound revealed the presence of an intraocular mass. On the day of surgery, the cornea was perforated with extrusion of neoplastic tissue. After enucleation, the globe was fixed in $10 \%$ formalin and submitted to histologic examination.

Case 2: A 10-year-old mixed breed queen with buphthalmia of the right eye (Fig. 1). According to the owner, buphthalmia had developed in the previous week and the left eye had been hypotonic for over nine years, with no changes during this period. The animal was also an adopted stray cat, and thus, the cause of the hypotonia could not be determined. Ophthalmologic evaluation revealed glaucoma in the right eye and phthisis bulbi in the left eye with no additional alterations in this eye.

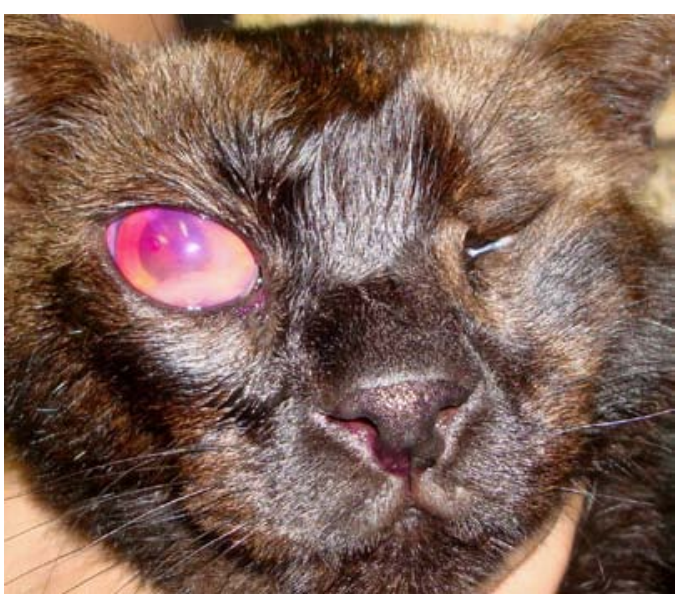

Figure 1. Cat 1: a 10-year-old, female, Domestic Short-haired cat presented with an old phthisis bulbi in the left eye and a recent developed glaucoma in the right eye secundary to a granulomatous uveitis non-related with the sarcoma
After bilateral subconjunctival enucleation, the eyes were fixed in $10 \%$ formalin and submitted to histologic examination. Immunohistochemical examinations for vimentin, cytokeratin, S-100, CD3, and CD79a were also carried out.

Histologic examination revealed intraocular malignant neoplasms of mesenchimal origin in both animals. The tumors occupied the entire intraocular cavity (Fig. 2 and 3). Cat 1 presented tumor invasion of the sclera, optic nerve, and perforation of the cornea. On the other hand, cat 2 did not present tumor invasion neither of sclera nor optic nerve. Nevertheless, they developed neurologic symptoms a few months after surgery and were humanely killed. Unfortunately, both cats were unavailable for necropsy. Yet, it was suspected that neurologic symptoms resulted from the invasion of the central nervous system by neoplastic cells from the eye.

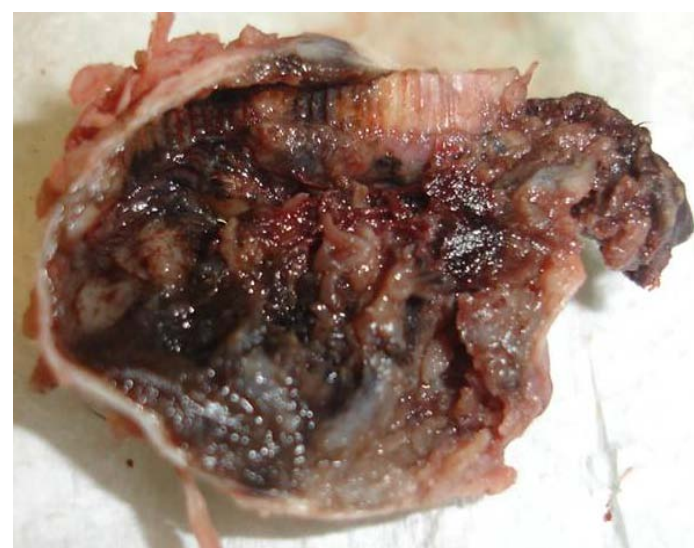

Figure 2. Cat 1. Sagital section of the left eye. The neoplasia is occupying the entire intraocular space.

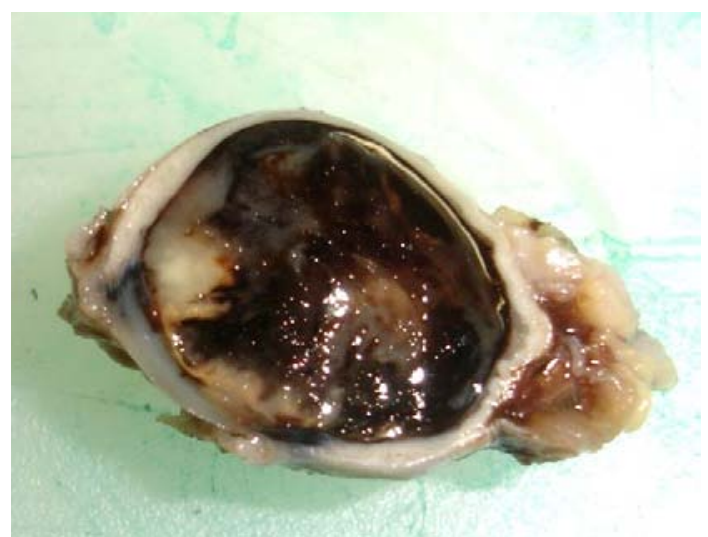

Figure 3. Cat 2. Sagital section of the left eye. The neoplasia is occupying the entire intraocular space. 
In the cat 1 , the histologic examination revealed that the neoplastic tissue was composed of spindle shaped cells, with a high degree of pleomorphism and atypia (Fig. 4), and was compatible with intraocular fibrosarcoma. Mitoses were frequently observed. The microscopic examination of the cat 2 eye revealed neoplastic round cells, with a high degree of pleomorphism, evident nucleolus, and cellular atypia. There were cells presenting intracytoplasmic melanine granules (Fig. 5). Mitoses were frequent. The immunohistochemical examination was negative for CD3, CD79a, cytokeratin, and S-100, and positive for vimentin. Based on the immunohistochemical results, a diagnosis of intraocular anaplastic sarcoma was made. In both cases, the lens had been completely destroyed and only the capsules could be identified.

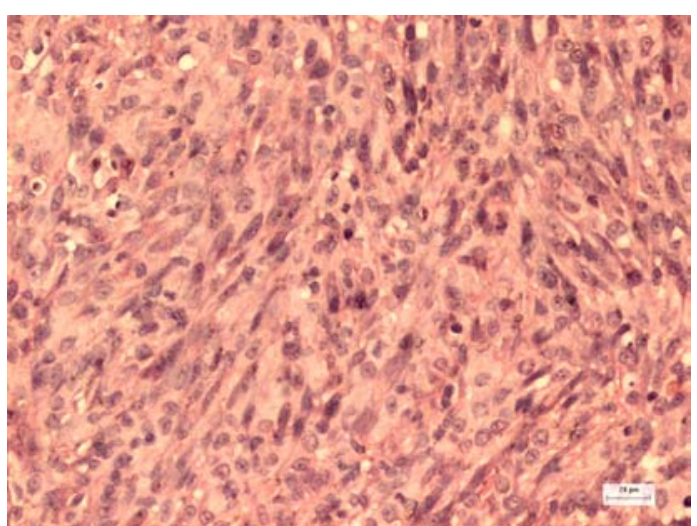

Figure 4. Cat 1. Microphotograph showing neoplastic spindle cells, pleomorphism, and atypia (H\&E stain).

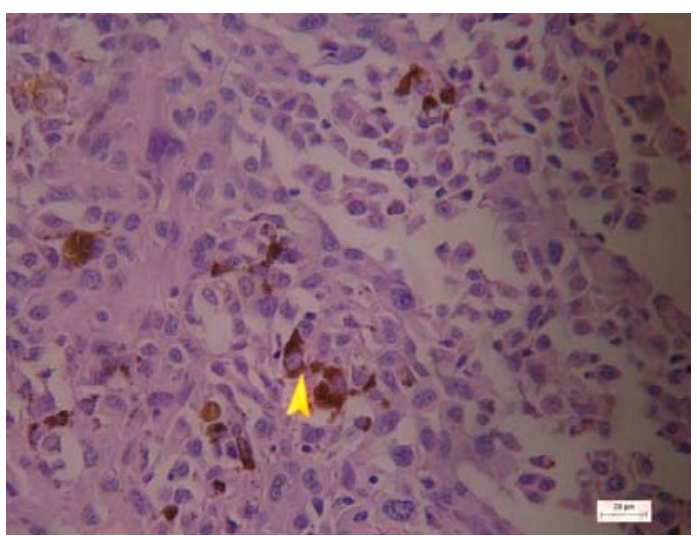

Figure 5. Cat 2. Microphotograph showing neoplastic round cells, pleomorphism, and atypia. There were cells presenting intracytoplasmic melanin granules (arrow). (H\&E stain).

\section{DISCUSSION}

Herein two cases of feline intraocular sarcoma are described: an invasive malign neoplasm, which invades the iris; ciliary body; and anterior, posterior, and vitreous chambers, with a frequent history of previous ocular trauma. According to Dubielzig et al. (1990) and Grahn et al. (2006), the lens are always destroyed and a severe inflammatory process is associated with tumor development.

The characteristics of feline intraocular sarcoma resemble those of feline post-vaccination sarcomas (Carter et al., 2005). One explanation is that certain cats might be genetically predisposed to develop this neoplasia in the presence of inflammatory or regenerative processes. The cells lose their antiproliferative properties and become malignant. In these cases, telomerase levels are increased. According to these authors, feline intraocular sarcoma is not associated with any viral infection.

Animals usually show no signs of pain or irritation (Dubielzig et al., 1990). In the cases herein reported, both animals had a history of years with no sign of discomfort. Yet, cat 1 presented some degree of discomfort due to the recent corneal rupture caused by the tumor, whereas cat 2 presented discomfort in the right eye, which was affected by glaucoma secondary to uveitis of unknown cause.

In cases of cataract, the epithelium of lens suffers differentiation into myofibroblasts and it is possible to induce crystalline neoplasias in certain rats. Thus, Zeiss et al. (2003) suggested that sarcomas originate from the crystalline, and their findings sustain the hypothesis that inflammation precedes the development of neoplasia and might cause neoplastic changes inside the eye.

In the present study, both animals presented phthisis bulbi prior to neoplasia diagnosis. This suggests that they had chronic intraocular inflammation and atrophy of the ciliary body. The owner of cat 1 reported no change in the affected eye, prior to the onset of symptoms enlargement of the eye a month prior to presentation. The owner of cat 2 did not report any alteration of the phthical eye. Since both were adopted stray cats, it was not possible to 
know whether they had suffered any ocular trauma or not. Since eyes presenting phthisis bulbi are blind, small, opaque, and not painful, they are frequently not monitored. Yet, these reports show that inadequate monitoring of cats presented in this condition may result in late diagnosis of neoplasia development.

From the histologic point of view, FIS can be highly variable and have different microscopic presentations (Dubielzig et al., 1990). These tumors are composed of spindle shaped cells that originate from the fibrous metaplasia of the crystalline epithelium (Dubielzig, 2002). Another form of tumor presentation is the presence of lymphoid cells. In an advanced case, the tumor destroys the entire intraocular architecture and invades the optic nerve. Due to the different microscopic presentations, immunohistochemistry may be an important diagnostic tool. In the present study, there were two microscopic presentations. Therefore, amelanotic melanoma should be considered as a differential diagnosis (Grahn et al., 2006). In all cases reported so far, the crystalline had been completely destroyed and only the capsules could be identified.

Treatment of FIS is early enucleation (Dubielzig et al., 1990). Eyes with a history of trauma should be regularly monitored and enucleated if necessary. The two cases herein reported underwent enucleation of the affected eye.

The impact of FIS on the life expectancy of the affected cat is significant. The average survival time is seven to 11 months. If the sclera has been compromised, life expectancy might be further reduced. Prognosis is reserved and most cats die due to metastases that reach the central nervous system through the optic nerve, recidivation, or distant metastasis. Little is known about the efficacy of treatments that could be used in combination with enucleation, such as radiotherapy, chemotherapy, and immunotherapy (Budelsky and Dubielzig, 2002; Dubielzig, 2002).

\section{CONCLUSIONS}

Animals presented phthisis bulbi prior to neoplasia diagnosis, suggesting that both had chronic intraocular inflammation and atropy of the ciliary body. Phthisis bulbi was not monitored because eyes were blind, small, opaque, and not painful. Yet, monitoring those eyes and early enucleating are important and the latter should be considered as treatment of option, because feline intraocular sarcoma is an aggressive tumor that significantly decreases life expectancy.

\section{REFERENCES}

BUDELSKY, C.L.; DUBIELZIG, R.R. Follow-up study of cats previously diagnosed with post traumatic sarcoma and possible effects on lifespan (abstract). In: MEETING OF THE AMERICAN COLLEGE OF VETERINARY OPHTHALMOLOGY, 2002, Denver, CO, USA; Vet. Ophth., v.5, p.300, 2002.

CARTER, R.T.; GIUDICE, C.; DUBIELZIG, R.R. et al. Telomerase activity with concurrent loss of cell cycle regulation in feline post-traumatic ocular sarcomas. J. Comp. Path., v.133, p.235-245, 2005.

DUBIELZIG, R.R. Feline ocular sarcoma. In: PEIFFER, R.L.; SIMONS, K.B. Ocular Tumors in Animals and Humans. 4.ed. Ames, IW: Iowa State, 2002. p.283-288.

DUBIELZIG, R.R.; EVERITT, J.; SHADDUCK, J.A. et al. Clinical and morphologic feature of posttraumatic ocular sarcoma in cats. Vet. Pathol., v.27, p.62-65, 1990.

GRAHN, B.H.; PEIFFER, R.L.; CULLEN, C.L. et al. Classification of feline intraocular neoplasms based on morphology, histochemical staining, and immunohistochemical labeling. Vet. Ophth., v.9, p.395-403, 2006.

STOLTZ, J.H.; CARPENTER, J.L.; ALBERT, D.M. et al. Histologic, immunohistochemical, and ultrastructural features of an intraocular sarcoma of a cat. Vet. Diagn. Invest., v.6, p.114-116, 1994.

ZEISS, C.J.; JOHNSON, M.L.; DUBIELZIG, R.R. Feline intraocular tumors may arise from transformation of lens epithelium. Vet. Pathol., v.40, p.355-362, 2003. 